\title{
Bazı Arpa Çeşitlerinin Topraksız Ortamda Yeşil Yem Performanslarının Belirlenmesi
}

\author{
Muhammet Karaşahin ${ }^{\star}$ \\ Necmettin Erbakan Üniversitesi, Mühendislik ve Doğa Bilimleri Fakültesi, Biyosistem Mühendisliği Bölümü, \\ Konya
}

Geliş tarihi (Received): 25.04.2017～Kabul tarihi (Accepted): 03.07.2017

\section{Anahtar kelimeler:}

Arpa çeşitleri, hidroponik, yeşil yem

\section{*Sorumlu yazar}

mkarasahin@konya.edu.tr

\begin{abstract}
Özet. Araştırma bazı arpa çeşitlerinin topraksız ortamda yeşil yem performanslarının belirlenmesi amacıyla yürütülmüştür. Araştırma sonuçlarına göre farklı çeşitler arasında en yüksek yeşil yem verimi ve yeşil yem tohum oranı Atılır çeşidinden elde edilmiştir. En yüksek kuru madde oranı, $\mathrm{P}$ ve $\mathrm{Mn}$ değerleri Kral-97 çeşidinden elde edilirken en düşük kuru madde kaybı Hilal ve Akhisar-98 çeşitlerinden elde edilmiştir. Yeşil yem verimi ve yeşil yem tohum oranı ${ }^{-1}$ değerleri artarken kuru madde oranı değerlerinin düştüğü ve kuru madde kayıplarının arttığı görülmüştür. En yüksek ham protein kazançları Atılır ve Hilal çeşitlerinden elde edilmiş̧ir. En yüksek bitki boyu, ham protein, ham yağ, ADL, N ve Mg değerleri Karatay-94 çeşidinden elde edilirken, en yüksek kök uzunluğu değerleri Akhisar-98 çeşidinden elde edilmiştir. En yüksek ham kül, ham selüloz, ADF ve NDF değerleri sırasıyla Akhisar-98, Tarm-92, Aydanhanım, ve Atılır çeşitlerinden elde edilmiştir. En yüksek metabolik enerji değerleri ise Zeynelağa çeşidinden elde edilmiştir. En yüksek K ve Na değerleri Tarm-92 çeşidinden elde edilirken en yüksek Zn değerleri ise Gazda çeşidinden elde edilmiştir. En yüksek Ca değerleri Aydanhanım ve Lord çeşitlerinden elde edilirken, en yüksek Fe değerleri Aydanhanım, Tarm-92 ve Karatay-94 çeşitlerinden elde edilmiştir. En yüksek Cu değerleri ise Gazda, Kral-97, Atılır ve Hilal çeşitlerinden elde edilmiştir. Yüksek yeşil yem verimi ve ham protein kazançları dikkate alındığında Atılır çeşidinin, düşük kuru madde kaybı ve yüksek ham protein kazançları dikkate alındığında Hilal çeşidinin dikkati çektiği görülmektedir. Metabolik enerji değerleri göz önünde bulundurulduğunda ise Zeynelağa çeşidi tavsiye edilebilir niteliktedir.
\end{abstract}

\section{The Determination of Green Fodder Performance of Some Barley Varieties in Soilles Condition}

\section{Keywords:}

Barley varieties, green

fodder, hydroponic

\begin{abstract}
This research was conducted to the determination of green fodder performance of some barley varieties in soilless condition. According to the results of the research, the highest green fodder yield and green fodder seed ratio were obtained from Atılır among different varieties. The lowest dry matter losses were obtained from Hilal and Akhisar-98 varieties when the highest dry matter ratio, $\mathrm{P}$ and $\mathrm{Mn}$ values were obtained from Kral-97 variety. It was seen that dry matter ratio values were decreased and dry matter losses were increased while the green fodder yield and green fodder seed ratio- values were increased. The highest crude protein gains were obtained from Atılır and Hilal varieties. The highest root length values were obtained from Akhisar- 98 variety while the highest plant height, crude protein, crude oil, ADL, N and Mg values were obtained from Karatay-94 variety. The highest crude ash, crude cellulose, ADF and NDF values were obtained from Akhisar-98, Tarm-92, Aydanhanım, and Atılır varieties respectively. The highest metabolic energy values were obtained from Zeynelaga variety. The highest $Z n$ values were obtained from Gazda variety while the highest $\mathrm{K}$ and $\mathrm{Na}$ values were obtained from the Tarm-92 variety. The highest Fe values were obtained from Aydanhanım, Tarm-92 and Karatay-94 varieties while the highest $\mathrm{Ca}$ values were obtained from Aydanhanım and Lord varieties. The highest $\mathrm{Cu}$ values were obtained from Gazda, Kral-97, Atılır and Hilal varieties. The lowest dry matter losses and highest crude protein gains are taken into consideration Hilal variety come into the forefront while the high green fodder yield and crude protein gains are taken into consideration Atılır variety come into the forefront. When the metabolic energy values are taken into consideration Zeynelağa variety can be recommended.
\end{abstract}




\section{GíRiş}

Artan nüfusla birlikte hayvansal gıdalara olan talepte artmaktadır. Hayvan varlığımızda görülen artışa rağmen yem bitkileri ekim alanlarının istenilen seviyeye ulaşmaması ve çayır mera alanlarımızın aşırı otlatma ve bakımsızlıktan zayıf kalmaları hayvanların kaba yem intiyaçlarını karşılamada yetersiz kalmaktadır (Topal 1993). Bununla birlikte hayvan varlığımızın ıslah çalışmaları ile entansif tarıma daha yatkın hale gelmesi, ülkemizdeki kaba yem açığının giderek artmasına neden olmuştur. Mevcut kaba yem üretimimiz, toplam kaba yem ihtiyacımızın yaklaşık yarısını karşılayabilmektedir. Bu nedenle, hayvancılık işletmelerinin kaliteli kaba yem gereksinimini karşılamak için çayır meraların ıslahı, yem bitkisi üretim alanlarının artırıması, ucuz ve alternatif diğer kaba yem kaynaklarının hayvansal üretime kazandırılması ve kaliteli kaba yem üretim tekniklerinin üreticilere aktarılması gerekmektedir (Yolcu ve Tan 2008; Alçiçek ve ark., 2010).

Topraksız ortamda çimlendirilmiş tahıl tohumları özellikle kuraklık yaşanan bölgelerde hayvancılık yapan çiftçiler için alternatif yeşil yem kaynağı olarak önerilmektedir. Arpa çimi, ön ıslatma sonrası arpa tohumlarının tavalarda 6-8 gün çimlendirme ve filizlendirmeye tabi tutulmasıyla elde edilmektedir. Bu süre sonunda elde edilen halı gibi birbirine geçmiş kökler ile yeşil sürgünler hayvan yemi olarak kullanılmaktadır. Filizlenme sonunda arpa tanelerinde önemli miktarda ağırlık artışı olmakta ve çimlenme ile tanede bulunan nişasta, protein ve yağ bileşikleri şeker, aminoasit ve yağ asitleri gibi basit formlara dönüşmektedir. Bunun sonucunda hayvanların bağışıklık sistemleri güçlenmekte sağlık ve performanslarında artış sağlanmaktadır. Ayrıca yılın her günü kaliteli yeşil yem üretiminin yapılabilmesi hidroponik yeşil yem üretim sistemlerini gün geçtikçe yaygınlaştırmaktadır (Dung et al., 2010; Fazaeli et al., 2012; Hafla et al., 2014). Arpa tanesi bünyesinde bulundurduğu yaklaşık \%67 karbonhidrat, \%10 protein, \%2 yağ, \%5 selüloz ve kalsiyum, fosfor, potasyum gibi mineraller ile $A$ vitamini, $E$ vitamini ve $B$ vitamini içeriği ile hayvanların beslenmesinde önemli bir yere sahiptir (Alkan ve Kandemir 2015). Genetik ve çevresel faktörlerin arpanın tane kompozisyonu üzerine önemli etkiler yaptığı bu konuda daha önce yapılmış çalışmalarda belirlenmiştir (Guo et al., 2003; Alkan ve Kandemir 2015). Çeşidin genetik potansiyeli kalitenin değişim sınırlarını belirlerken, çeşidin yetiştirildiği çevre şartları ve uygulanan yetiştirme paketi genetik kapasitenin sınırları içinde kalitede varyasyonu sağlayıcı bir etkiye sahip olmaktadır (Topal ve ark., 2015). Topraksız ortamda yeşil arpa çimi üretiminde farklı çeşitlerin kullanılması ile yeşil yem kompozisyonunda farkılıkların elde edileceği varsayılmaktadır.

Bu çalışma ile farklı arpa çeşitleri topraksız ortamda yetiştirilerek en uygun yeşil yem performansına sahip çeşitlerin belirlenmesi amaçlanmıştır.

\section{MATERYAL VE METOD}

Araştırma, Karabük Üniversitesi, Eskipazar Meslek Yüksekokulu, Bitkisel ve Hayvansal Üretim Bölümünün $3 \times 3 \times 2.1 \mathrm{~m}$ boyutlarındaki hidroponik yeşil yem üretim odasında 01.03.2016 ile 01.06.2016 tarihleri arasında yürütülmüştür. Çimlendirme kabı olarak 100 x $10 \mathrm{~cm}$ plastik küvetler kullanılmıştır. Araştırmada bitki materyali olarak kullanılan arpa çeşitleri ve bazı özellikleri ile ilgili bilgiler Çizelge 1 'de verilmiştir.

Çizelge 1. Araştırmada kullanılan arpa çeşitleri ve bazı özellikleri.

Table 1. Barley varieties used in research and some properties.

\begin{tabular}{llcccc}
\hline $\begin{array}{l}\text { Çeşit } \\
\text { Adı }\end{array}$ & $\begin{array}{c}\text { Başak } \\
\text { Yapısı }\end{array}$ & $\begin{array}{c}\text { Kullanım } \\
\text { Alanı }\end{array}$ & $\begin{array}{c}\text { Gelişme } \\
\text { Tabiatı }\end{array}$ & $\begin{array}{c}\text { Bin Tane } \\
\text { Ağırlığı (g) }\end{array}$ & $\begin{array}{c}\text { Elde Edildiği } \\
\text { Kuruluş }\end{array}$ \\
\hline Gazda & 2 sıralı & yemlik & kışık & 46 & Tareks \\
Aydanhanım & 2 sıralı & maltık & kışlık & 53 & Tarla Bit. Merkez Araşt. Enst. \\
Tarm-92 & 2 sıralı & yemlik & alternatif & 37 & Tarla Bit. Merkez Araşt. Enst. \\
Zeynelağa & 2 sıralı & maltık & alternatif & 50 & Tarla Bit. Merkez Araşt. Enst. \\
Karatay-94 & 2 sıralı & yemlik & alternatif & 56 & Bahri Dağdaş U. Tar. Araşt. Enst. \\
Atılır & 2 sıralı & maltlık & yazlık & 39 & Efes \\
Hilal & 2 sıralı & yemlik & yazlık & 54 & Ege Tarımsal Araşt. Enst. \\
Akhisar-98 & 6 sıralı & yemlik & yazlık & 51 & Ege Tarımsal Araşt. Enst. \\
Lord & 6 sıralı & yemlik & kışık & 37 & Tareks \\
Kral-97 & 6 sıralı & yemlik & alternatif & 39 & Bahri Dağdaş U. Tar. Araşt. Enst. \\
\hline
\end{tabular}


Tüm uygulamalarda ön ıslatma süresi olarak $24 \mathrm{~h}$, tohum yoğunluğu olarak $2.2 \mathrm{~kg} \mathrm{~m}^{-2}$, ortam sıcaklığı olarak $20{ }^{\circ} \mathrm{C}$, ortam nemi olarak \%60, dezenfeksiyon yöntemi olarak ozon, yetiştirme süresi olarak 10 gün, ışıklanma süresi ve rengi olarak $24 \mathrm{~h}$-sarı ışık (50000 lux), sulama yöntemi, süresi ve sıklığı olarak gelgit, 60 sn $120 \mathrm{dk}^{-1}$, gübre kaynağı olarak 375 ppm deniz yosunu, $\mathrm{CO}_{2}$ dozu olarak 1000 ppm uygulanmıştır (Çizelge 2).

Çizelge 2. SeaMax deniz yosunu (Ascophyllum nodosum) özü içeriği.

Table 2. SeaMax seaweed (Ascophyllum nodosum) extract content.

\begin{tabular}{llcl}
\hline Özellikler (\%) & \multicolumn{3}{c}{ Özellikler (\%) } \\
\hline Organik madde & 47.5 & $\mathrm{~S}$ & 2.5 \\
Azot & 0.75 & $\mathrm{Fe}$ & 0.004 \\
Fosfor & 0.02 & $\mathrm{~B}$ & 0.006 \\
Potasyum & 14.9 & $\mathrm{Zn}$ & 0.006 \\
$\mathrm{Ca}$ & 0.3 & $\mathrm{Cu}$ & 0.0002 \\
$\mathrm{Mg}$ & 0.2 & Alginik asit & 5.5 \\
\hline
\end{tabular}

Çalışmada; farklı arpa çeşitlerinin yeşil yem verimi, yeşil yem tohum oranı ${ }^{-1}$, kuru madde oranı ve kaybı, ham protein kazancı, bitki boyu ve kök uzunluğu, ham besin madde (ham protein, kül, yağ ve selüloz) içerikleri, hücre duvarı bileşenleri (NDF, $A D F, A D L)$ ve metabolik enerji değerleri incelenmiştir.

Işık kaynağı olarak $600 \mathrm{~W}$ Osram Plantastar HPS (High Pressure Sodium) lambaları kullanılmıştır. Işık şiddeti ölçümünde TES 1335 marka ışık ölçme cihazı kullanılmıştır. İstenilen $\mathrm{CO}_{2}$ dozunu sağlamak için elektronik sensor ve valf ile kumanda edilen $\mathrm{CO}_{2}$ tüpü ile $1500 \mathrm{~m}^{3} \mathrm{~h}^{-1}$ debili salyangoz fandan yararlanılmıştır. Sulama sisteminde su kaynağı olarak şehir şebekesinden yararlanılmıştır (Çizelge 3).

Yeşil yem ağırlığı tartıldıktan sonra 200'er g örnekler alınarak $105^{\circ} \mathrm{C}$ altında etüvde sabit ağırlığa ulaşıncaya kadar bekletilerek hassas terazide tartılmış elde edilen değerler yeşil yem ağırlığına oranlanarak kuru madde oranları belirlenmiştir. Yeşil yem tohum oranı, yeşil yem kuru madde oranı değerleriyle çarpılmış elde edilen toplam yeşil yem kuru madde yüzdesi ile tohum kuru madde yüzdesi arasındaki farkın tohum kuru madde yüzdesine oranlanmasıyla kuru madde kayıpları hesap edilmiştir. Elde edilen toplam kuru madde miktarı ile ham protein oranı çarpılarak toplam ham protein verimleri hesap edilmiş ve bu değerlerle tohumun ham protein oranı ile kuru madde miktarı değerleri çarpımı ile oranlanarak ham protein kazançları hesap edilmiştir. Ham kül (AACC 08-
01), ham protein (AACC 46-12), ham yağ (AACC 30-25) ve ham selüloz analizleri (AACC 32-10)'a göre dış laboratuvarda yaptırılmış enerji içeriği hesabında aşağıdaki formülden yararlanılmıştır (TSE 2008).

$$
\begin{aligned}
\mathrm{ME}\left(\mathrm{kcal} \mathrm{kg}^{-1}\right)= & 3260+[0.455 \times \mathrm{HP} \%]+[3.517 \times \mathrm{HY} \%]- \\
& {[4.037 \times \mathrm{HS} \%] }
\end{aligned}
$$

ME: Metabolik enerji, HP: Ham protein, HY: Ham yağ, HS: Ham selüloz

NDF (Nötr deterjan lif), ADF (Asit deterjan lif) ve ADL (Asit deterjan lignin) analizleri Van Soest and Robertson (1985)'e göre dış laboratuvarda yaptırılmıştır.

Denemeler tekrarlanan tesadüf parselleri deneme desenine göre 3 tekerrürlü olarak yürütülmüştür. Elde edilen veriler varyans analizine tabi tutularak $F$ testi yapılmak suretiyle farklılıkları tespit edilen işlemlerin ortalama değerleri "Tukey-Kramer HSD" önem testine göre gruplandırılmıştır (JMP 2007).

Çizelge 3. Sulama suyu özellikleri.

\begin{tabular}{|c|c|c|c|}
\hline \multirow{2}{*}{$\begin{array}{l}\text { Özellikler } \\
\mathrm{pH}\end{array}$} & \multicolumn{3}{|c|}{ Özellikler $\left(\mathrm{mg} \mathrm{l}^{-1}\right)$} \\
\hline & 6.98 & $\mathrm{Zn}$ & 0.94 \\
\hline $\mathrm{EC}\left(\mathrm{mS} \mathrm{cm}^{-1}\right)$ & 0.59 & $\mathrm{P}$ & 0.20 \\
\hline $\mathrm{Ca}\left(\mathrm{mg} \mathrm{|} \mathrm{I}^{-1}\right)$ & 116.8 & $\mathrm{~K}$ & 0.03 \\
\hline $\mathrm{Mg}\left(\left.\mathrm{mg} \mathrm{|}\right|^{-1}\right)$ & 10.7 & $\mathrm{Mn}$ & 0.02 \\
\hline $\mathrm{Na}\left(\mathrm{mg} \mathrm{l}^{-1}\right)$ & 2.93 & $\mathrm{Cu}$ & 0.02 \\
\hline
\end{tabular}

Table 3. Irrigation water features.

\section{BULGULAR VE TARTIŞMA}

\section{Yeşil Yem Verimi, Yeşil Yem Tohum Orant ${ }^{-1}$}

Araştırmaya dahil edilen çeşitler arasında en yüksek yeşil yem verimi (11.9) ve yeşil yem tohum ${ }^{-1}$ oranı (5.45) Atılır çeşidinden elde edilmiştir $(P<0.01)$. Bu çeşidi Zeynelağa ve Tarm-92 çeşitleri sırasıyla 11.44 ve 11.20 yeşil yem verimi değerleri ve 5.20 ve 5.09 yeşil yem tohum ${ }^{-1}$ oranı değerleri ile izlemişlerdir. En düşük yeşil yem verimi (6.60) ve yeşil yem tohum ${ }^{-1}$ oranı (3.00) ise Kral-97 çeşidinden elde edilmiştir (Çizelge 4). Al-Karaki and Al-Momani (2011) bazı arpa çeşitlerinin hidroponik ortamda su kullanım etkinliklerini belirlemek amacıyla yürüttükleri çalışmada çeşitlerin yeşil yem tohum ${ }^{-1}$ oranı değerleri 4.74 ile 6.0 arasında değişiklik gösterirken, benzer konuda Emam (2016) yürüttüğü çalışmada çeşitlerin yeşil yem tohum ${ }^{-1}$ oranlarının 4.4 ile 6.7 arasında değişiklik gösterdiğini bildirmiş̧ir. Yousof et al. (2017) Mısır'da yürütmüş oldukları çalışmada farklı yerel çeşitler arasında 4.5 ile 5.5 kat arasında yeşil yem tohum ${ }^{-1}$ oranı değerleri elde etmişlerdir. Aynı araştırmalarda çeşitler arasında farklı değerler elde edilmesi bin dane ağırlığı, kavuz kalınlığı, 
Çizelge 4. Farklı çeşitlerin yeşil yem verimi, yeşil yem tohum oranı ${ }^{-1}$, kuru madde oranı ve kaybı, ham protein kazancı, bitki boyu ve kök uzunluğu üzerine etkileri.

Table 4. The effects of different varieties on green fodder yield, green fodder seed ratio-1, dry matter ratio and loss, crude protein gain, plant height and root length.

\begin{tabular}{|c|c|c|c|c|c|c|c|}
\hline Çeşitler & $\begin{array}{c}\text { Yeşil yem } \\
\text { verimi } \\
\left(\mathrm{kg} \mathrm{m}^{-2}\right) \\
\end{array}$ & $\begin{array}{c}\begin{array}{c}\text { Yeşil yem } \\
\text { tohum } \\
\text { oranı }^{-1}\end{array} \\
\end{array}$ & $\begin{array}{c}\text { Kuru madde } \\
\text { oranı } \\
(\%) \\
\end{array}$ & $\begin{array}{c}\text { Kuru madde } \\
\text { kaybı } \\
(\%) \\
\end{array}$ & $\begin{array}{c}\text { HP } \\
\text { kazancı } \\
(\%) \\
\end{array}$ & $\begin{array}{l}\text { Bitki } \\
\text { boyu } \\
(\mathrm{cm})\end{array}$ & $\begin{array}{c}\text { Kök } \\
\text { uzunluğu } \\
(\mathrm{cm})\end{array}$ \\
\hline Gazda & $10.10 \mathrm{de}$ & $4.59 \mathrm{de}$ & $15.87 \mathrm{c}$ & $20.9 c$ & $9.5 \mathrm{~cd}$ & $12.5 \mathrm{~d}$ & $12.5 \mathrm{c}$ \\
\hline Aydanhanı & 9.50 ef & 4.32 ef & $16.57 \mathrm{c}$ & $22.3 b$ & $10.6 \mathrm{bc}$ & $14.0 \mathrm{c}$ & $10.0 \mathrm{~d}$ \\
\hline Tarm-92 & $11.20 \mathrm{abc}$ & $5.09 \mathrm{abc}$ & $13.58 d$ & $23.2 \mathrm{~b}$ & $9.3 \mathrm{~cd}$ & $15.5 \mathrm{~b}$ & $14.5 \mathrm{~b}$ \\
\hline Zeynelağa & $11.44 \mathrm{ab}$ & $5.20 \mathrm{ab}$ & $13.27 d$ & $24.8 \mathrm{a}$ & $1.5 \mathrm{f}$ & $16.0 \mathrm{~b}$ & $12.0 \mathrm{c}$ \\
\hline Karatay-94 & $10.76 \mathrm{bcd}$ & $4.89 \mathrm{bcd}$ & $15.54 \mathrm{c}$ & $16.9 \mathrm{e}$ & $11.7 \mathrm{~b}$ & $20.0 \mathrm{a}$ & $14.0 \mathrm{~b}$ \\
\hline Atılır & 11.99 a & $5.45 \mathrm{a}$ & $13.77 \mathrm{~d}$ & $18.6 \mathrm{~d}$ & $17.8 \mathrm{a}$ & $14.0 \mathrm{c}$ & $10.0 \mathrm{~d}$ \\
\hline Hilal & $9.00 \mathrm{fg}$ & $4.09 \mathrm{fg}$ & $19.00 \mathrm{~b}$ & $14.9 \mathrm{f}$ & $17.8 \mathrm{a}$ & $16.0 \mathrm{~b}$ & $8.0 \mathrm{e}$ \\
\hline Akhisar-98 & $8.29 \mathrm{~g}$ & $3.77 \mathrm{~g}$ & $20.60 \mathrm{~b}$ & $14.7 \mathrm{f}$ & $8.3 \mathrm{~d}$ & $14.0 \mathrm{c}$ & $17.0 \mathrm{a}$ \\
\hline Lord & 10.34 cde & 4.70 cde & $14.88 \mathrm{~cd}$ & $23.4 \mathrm{~b}$ & $-2.8 \mathrm{~g}$ & $13.0 \mathrm{~cd}$ & $9.5 \mathrm{~d}$ \\
\hline Kral-97 & $6.60 \mathrm{~h}$ & $3.00 \mathrm{~h}$ & $25.10 \mathrm{a}$ & $17.6 \mathrm{de}$ & $3.5 \mathrm{e}$ & $14.0 \mathrm{c}$ & $9.0 \mathrm{de}$ \\
\hline HSD & $0.36^{\star \star}$ & $0.28^{* \star}$ & $1.23^{* *}$ & $0.83^{* *}$ & $1.15^{\star *}$ & $0.92^{\star *}$ & $0.73^{* \star}$ \\
\hline
\end{tabular}

*; $\mathrm{P}<0.05$, **; $\mathrm{P}<0.01, \mathrm{HSD}$; Güvenilir önemli fark, Ns; Önemli değil.

endosperm karakterleri ile genetik yapı farklılığından kaynaklandığı varsayılmaktadır (Lee et al., 2002; Yousof et al., 2017).

\section{Kuru Madde Oranı ve Kaybı}

En yüksek (25.10) kuru madde oranı Kral-97 çeşidinden elde edilmiştir $(P<0.01)$. Bu çeşidi Akhisar ve Hilal çeşitleri sırasıyla 20.60 ve 19.00 kuru madde oranı değerleri ile izlemişlerdir. En düşük değerler ise Atılır, Tarm-92 ve Zeynelağa çeşitlerinden elde edilmiştir (sırasıyla 13.77, 13.58 ve 13.27). En yüksek kuru madde kaybı (24.8) Zeynelağa çeşidinden elde edilmiştir $(P<0.01)$. Bu çeşidi Lord, Tarm-92 ve Ayadanhanım çeşitleri izlemiştir (sırasıyla, 23.4, 23.2 ve 22.3). En düşük kuru madde kaybı Hilal ve Akhisar-98 çeşitlerinden elde edilmiştir (sırasıyla, 14.9 ve 14.7). Yeşil yem verimi ve yeşil yem tohum oranı ${ }^{-1}$ artışıyla birlikte kuru madde oranı değerlerinin düştüğü ve kuru madde kayıplarının arttığı görülmektedir (Çizelge 4). Farklı arpa çeşitlerinin kuru madde oranını belirlemeye yönelik yapılmış araştırmalarda Al-Karaki and Al-Momani (2011) \%11.9 ile 12.2, Emam (2016) \%13 ile 20, Yousof et al. (2017) \%10 ile13 arasında kuru madde oranı değerleri elde etmişlerdir. Hidroponik ortamda çimlenme ile birlikte metabolik aktivite ve solunum sonucu kuru madde kayıpları oluşmaktadır. Çimlenmenin 3. gününde kloroplast oluşumu ile fotosentez başlamakta ancak kısa sürede fotosentezle elde edilen kuru madde miktarı kayıpları karşılayamamaktadır (Dung et al., 2010; Karaşahin 2014). Akbağ ve ark. (2014) hasat zamanı uzadıkça kuru madde oranında önemli azalmalar olduğunu tespit etmişlerdir. Yetiştirme süresi uzadıkça yeşil yem verimi ile birlikte kuru madde kayıpları artmaktadır
(Karaşahin 2017). Benzer konularda yapılan araştırmalarda elde edilen kuru madde oranlarının önemli farklılık göstermesinin bitki besi elementi varlığı, sıcaklık, nem oranı, ışık yoğunluğu ve pozisyonu, tohum yoğunluğu ve yetiştirme süresi gibi uygulamalardan kaynaklanabileceği varsayılmaktadır.

\section{Ham Protein Kazancı, Bitki Boyu ve Kök Uzunluğu}

En yüksek ham protein kazancı Atılır ve Hilal çeşitlerinden elde edilmiştir (sırasıyla, 17.8 ve 17.8), $(P<0.01)$. Bu çeşitleri 11.7 ham protein kazancı değeriyle Karatay-94 çeşidi izlemiştir. En düşük değerler (-2.8) ise Lord çeşidinden elde edilmiştir (Çizelge 4). Karaşahin (2017) farklı gübreleme ve yetiştirme sürelerinin hidroponik arpa çimi üzerine etkilerini belirlemek amacıyla yürüttüğü çalışmada \%2.1 ile 12.4 arasında ham protein kazancı değerleri elde etmiştir.

En yüksek bitki boyu değerleri (20.0) Karatay-94 çeşidinden elde edilmiştir $(P<0.01)$. Bu çeşidi Zeynelağa, Hilal ve Tarm-92 çeşitleri izlemiştir (sırasıyla, 16.0, 16.0 ve 15.5). En düşük değerler (12.5) ise Gazda çeşidinden elde edilmiştir (Çizelge 4). AlKaraki and Al-Momani (2011) farklı çeşitler arasında hidroponik arpa çimi boyunu 18.7 ile $22.7 \mathrm{~cm}$ elde ederlerken Emam (2016) 6 ile $10 \mathrm{~cm}$, Yousof et al. (2017) 12 ile $16 \mathrm{~cm}$ arasında elde etmişler ve bunun sebebini besleme solüsyonu kullanmadan sulama yapılmasına bağlamışlardır.

En yüksek kök uzunluğu değerleri (17.0) Akhisar-98 çeşidinden elde edilmiştir ( $P<0.01)$. Bu çeşidi Tarm-92 ve Karatay-94 çeşitleri izlemiştir (sırasıyla, 14.5 ve 14.0). En düşük değerler (8.0) ise Hilal çeşidinden elde 
edilmiştir (Çizelge 4). Al-Karaki (2007) farklı çeşitler arasında 6.9 ile $7.9 \mathrm{~cm}$ kök uzunluğu değerleri elde ederken Karaşahin (2017) farklı gübreleme ve yetiştirme süreleri uygulamalarında 9.5 ile $14.7 \mathrm{~cm}$ arasında arpa çimi kök uzunluğu değerleri elde etmiştir.

\section{Ham Protein, Kül, Yağ, Selüloz}

Farklı çeşitler arasında en yüksek ham protein değerleri (18.95) Karatay-94 çeşidinden elde edilmiştir $(P<0.01)$. Gazda çeşidi 18.75 ham protein oranı ile Karatay-94 çeşidini takip etmiştir. En düşük değerler (15.48) ise Kral-97 çeşidinden elde edilmiştir (Çizelge 5). Emam (2016) hidroponik ortamda çimlendirdiği 6 arpa çeşidi arasında ham protein oranlarının \%9.1 ile 13.2 arasında değiştiğini belirtmiş̧ir. Al Ajmi et al. (2009) farklı dozda arıtılmış atık su uygulamaları ile hidroponik arpa çimi ham protein oranlarının \%13.7 ile 16.1 arasında değiştiğini bildirmişlerdir. Al Karaki and Al Momani (2011) hidroponik arpa çimi ham protein oranını \%25.2 olarak belirlerken, Akbağ et al. (2014) hasat zamanı ile hidroponik arpa çimi ham protein oranlarının \%17.1 ile 18.2 arasında değişim gösterdiğini saptamışlardır. En yüksek ham kül değerleri (3.48) Akhisar-98 çeşidinden elde edilmiştir $(P<0.01)$. Kral-97 çeşidi 3.24 ham kül değeri ile Akhisar-98 çeşidini takip etmiştir. En düşük değerler (2.33) ise Hilal çeşidinden elde edilmiştir (Çizelge 5). Emam (2016) farklı çeşitler arasında \%2.27 ile 3.43 arası ham kül oranı değeriyle benzer sonuçlar elde etmiştir. En yüksek ham yağ değerleri (2.61) Karatay-94 çeşidinden elde edilirken, bu çeşidi 2.52 ham yağ değeri ile Tarm-92 çeşidinin izlediği görülmektedir (Çizelge 5). En düşük ham yağ değeri (2.34) Lord çeşidinden elde edilmiştir (Çizelge 5). Emam (2016) farklı çeşitler arasında \%2.72 ile 3.91 arası ham yağ oranı değerleri elde edildiğini bildirmektedir. Al Karaki and Al Momani (2011) \%4.2 ham yağ oranı elde ederlerken, Ata (2016) \%3.2 ham yağ oranı değerleri elde ettiğini belirtmektedir. En yüksek ham selüloz değerine (16.02) Tarm-92 çeşidinin sahip olduğu, bu çeşidi Akhisar-98 ve Kral-97 çeşitlerinin takip ettiği (sırasıyla, 11.67 ve 11.44) görülmüştür. En düşük değerler (10.09) ise Zeynelağa çeşidinden elde edilmiştir (Çizelge 5). Emam (2016) farklı çeşitler arasında \%8.43 ile 12.43 arasında değişim gösteren ham selüloz oranı değerleri elde etmiştir. Al Karaki and Al Momani (2011) \%12.4 ham selüloz oranı elde ederlerken, Ata (2016) \%11.4 ham selüloz oranı değerini elde etmiştir.

\section{NDF, ADF, ADL, Metabolik Enerji Değerleri}

En yüksek $A D L$ değerleri (7.86) Karatay-94 çeşidinden elde edilmiştir $(P<0.01)$. Bu çeşidi 7.43 ADL değeri ile Zeynelağa çeşidi takip etmiştir. En düşük değerler (3.17) Tarm-92 çeşidinden elde edilmiştir (Çizelge 5). En yüksek ADF değerleri (28.87) Aydanhanım çeşidinden elde edilirken, bu çeşidi 24.82 ADF değeri ile Karatay-94 çeşidinin izlediği gözlenmektedir. En düşük değerler (20.99) Tarm-92 çeşidinden elde edilmiştir (Çizelge 5). Al Karaki and Al Momani (2011) \%14.3 ADF değeri elde ederlerken Ata (2016) \%19.6 elde etmiştir. En yüksek NDF değerleri (44.16) Atılır çeşidinden elde edilmiştir $(P<0.01)$. Bu çeşidi 43.57 NDF değeri ile Gazda çeşidi takip etmiştir. En düşük değerler (35.63) Tarm-92 çeşidinden elde edilmiştir (Çizelge 5). Al Karaki and Al Momani (2011)

Çizelge 5. Farklı çeşitlerin ham besin madde içerikleri, hücre duvarı bileşenleri ve metabolik enerji değerleri üzerine etkileri. Table 5. The effects of different varieties on nutrient content, cell wall components and metabolic energy values.

\begin{tabular}{|c|c|c|c|c|c|c|c|c|}
\hline Çeşitler & $\begin{array}{l}\text { HP } \\
(\%) \\
\end{array}$ & $\begin{array}{l}\text { HK } \\
(\%) \\
\end{array}$ & $\begin{array}{l}\text { HY } \\
(\%) \\
\end{array}$ & $\begin{array}{l}\text { HS } \\
(\%)\end{array}$ & $\begin{array}{c}\text { ADL } \\
(\%) \\
\end{array}$ & $\begin{array}{l}\text { ADF } \\
(\%) \\
\end{array}$ & $\begin{array}{c}\text { NDF } \\
(\%) \\
\end{array}$ & $\begin{array}{c}\text { ME } \\
\left(k^{-1} k^{-1}\right)\end{array}$ \\
\hline Gazda & $18.75 \mathrm{ab}$ & $2.59 \mathrm{f}$ & $2.44 \mathrm{cde}$ & 10.28 ef & $6.87 c$ & $22.39 \mathrm{e}$ & $43.57 \mathrm{ab}$ & $3235.6 \mathrm{ab}$ \\
\hline Aydanhanı & $18.46 \mathrm{abc}$ & $2.71 \mathrm{e}$ & $2.51 b c$ & $10.74 \mathrm{~cd}$ & $5.31 \mathrm{f}$ & $28.87 \mathrm{a}$ & $40.54 \mathrm{~d}$ & $3233.9 \mathrm{de}$ \\
\hline Tarm-92 & $17.37 \mathrm{~d}$ & $3.09 c$ & $2.52 \mathrm{~b}$ & $16.02 \mathrm{a}$ & $3.17 \mathrm{~h}$ & $20.99 \mathrm{~g}$ & $35.63 \mathrm{e}$ & $3212.1 \mathrm{~h}$ \\
\hline Zeynelağa & $18.21 \mathrm{C}$ & $2.83 \mathrm{~d}$ & $2.49 \mathrm{bcd}$ & $10.09 \mathrm{f}$ & $7.43 \mathrm{~b}$ & 21.88 ef & $42.47 \mathrm{bc}$ & 3236.3 a \\
\hline Karatay-94 & $18.95 \mathrm{a}$ & 2.63 ef & $2.61 \mathrm{a}$ & $10.71 \mathrm{~cd}$ & $7.86 \mathrm{a}$ & $24.82 b$ & $43.27 \mathrm{abc}$ & $3234.6 \mathrm{~cd}$ \\
\hline Atılır & $18.64 \mathrm{abc}$ & $2.49 \mathrm{~g}$ & $2.46 \mathrm{bcd}$ & $10.48 \mathrm{de}$ & $6.37 \mathrm{e}$ & $24.14 \mathrm{c}$ & $44.16 \mathrm{a}$ & 3234.8 bc \\
\hline Hilal & $18.71 \mathrm{abc}$ & $2.33 \mathrm{~h}$ & 2.38 ef & $11.04 \mathrm{c}$ & $5.24 \mathrm{f}$ & $23.29 \mathrm{~d}$ & $42.22 \mathrm{c}$ & $3232.3 \mathrm{f}$ \\
\hline Akhisar-98 & $17.32 \mathrm{~d}$ & $3.48 \mathrm{a}$ & $2.43 \mathrm{de}$ & $11.67 \mathrm{~b}$ & $4.59 \mathrm{~g}$ & $21.26 \mathrm{fg}$ & $40.69 \mathrm{~d}$ & $3229.3 \mathrm{~g}$ \\
\hline Lord & 18.34 bc & 3.16 bc & $2.34 \mathrm{f}$ & $10.67 d$ & $6.55 \mathrm{~d}$ & 24.61 bc & $40.59 \mathrm{~d}$ & $3233.5 \mathrm{e}$ \\
\hline Kral-97 & $15.48 \mathrm{e}$ & $3.24 \mathrm{~b}$ & 2.37 ef & $11.44 \mathrm{~b}$ & $5.29 \mathrm{f}$ & $21.46 \mathrm{fg}$ & $40.88 d$ & $3229.2 \mathrm{~g}$ \\
\hline HSD & $0.37^{* \star}$ & 0.06 ** & $0.05^{\star *}$ & $0.23^{* \star}$ & $0.12^{* *}$ & $0.48^{\star \star}$ & $0.85^{\star *}$ & $0.61^{\text {** }}$ \\
\hline
\end{tabular}


değerlerini sırasıyla \%29.6 ve 14.3 olarak belirleyerek bu değerlerin tarla şartlarında yetiştirilen yoncanın NDF ve ADF değerlerinden (sırasıyla \%43 ve 34) daha düşük olduğunu belirterek eğer kaba yemin ADF değerleri < \%30-35, ve NDF değerleri de < \%40-45 ise o yemin besleyici değerlerinin gayet iyi olduğuna karar verilebileceğini ifade etmişlerdir. En yüksek metabolik enerji değerleri (3236.3) Zeynelağa çeşidinden elde edilmiştir $(P<0.01)$. Bu çeşidi 3235.6 metabolik enerji değeri ile Gazda çeşidi takip etmiştir. En düşük değerler (3212.1) Tarm-92 çeşidinden elde edilmiștir (Çizelge 5).

\section{Mineral madde içerikleri}

Araştırmada materyal olarak kullanılan çeşitler arasında en yüksek $N$ değerine (\%3.03) Karatay-94 çeşidi sahip olurken, Gazda çeşidinden 3.0 azot oranı bu çeşidi takip ettiği, en düşük $N$ değerine (\%2.48) ise Kral-97 çeşidinin sahip olduğu görülmektedir (Çizelge 6). En yüksek $P$ değerleri (0.88 ppm) Kral-97 çeşidinden elde edilmiştir $(P<0.01)$. Akhisar-98 çeşidinden 0.85 ppm fosfor miktarı elde edilerek bu çeşidi takip etmiştir. En düşük değerler (0.49) ise Hilal çeşidinden elde edilmiştir (Çizelge 6). En yüksek K değerleri (37.47) Tarm-92 çeşidinden elde edilmiş̧ir $(P<0.01)$. Lord çeşidinden $36.33 \mathrm{ppm}$ potasyum miktarı elde edilerek bu çeşidi takip etmiştir. En düşük değerler (34.23) ise Hilal çeşidinden elde edilmiştir (Çizelge 6). Aydanhanım ve Lord çeşitlerinden en yüksek $\mathrm{Ca}$ değerleri sırasıyla, 7.21 ve 7.11 ppm elde dilmiştir $(\mathrm{P}<0.01)$. Bu çeşitleri Hilal, Atılır ve Kral-97 çeşitleri takip ederek sırasıyla, $6.42,6.33$ ve 6.27 ppm kalsiyum miktarları elde edilmiştir. En düşük değerler (4.55) ise Gazda çeşidinden elde edilmiştir (Çizelge 6). Karatay94 çeşidinden en yüksek (7.09) Mg değerleri elde edilmiştir $(\mathrm{P}<0.01)$. Bu çeşidi Akhisar-98 çeşidi 6.54 ppm magnezyum miktarı ile takip etmiştir. En düşük değerler ise Lord ve Hilal çeşitlerinden elde edilmiştir (sırasıyla, 4.91 ve 4.87). Aydanhanım, Tarm-92 ve Karatay-94 çeşitlerinden en yüksek $\mathrm{Fe}$ değerleri sırasıyla, $0.58,0.57$ ve $0.57 \mathrm{ppm}$ elde edilmiştir $(P<0.01)$. Bu çeşitleri Zeynelağa çeşidi 0.53 ppm demir içeriğiyle takip etmiştir. En düşük değerler ise Gazda ve Akhisar-98 çeşitlerinden elde edilmiştir (sırasıyla, 0.39 ve 0.39) (Çizelge 6). Gazda, Kral-97, Atılır ve Hilal çeşitlerinden en yüksek $\mathrm{Cu}$ değerleri sırasıyla, 0.55, 0.55 ve 0.54 ppm elde edilmiştir $(P<0.01)$. Bu çeşitleri Zeynelağa çeşidi $0.45 \mathrm{ppm}$ bakır içeriğiyle takip etmiştir. En düşük bakır içerikleri (0.28) ise Tarm-92, Akhisar-98 ve Lord çeşitlerinden elde edilmiştir (Çizelge 6). En yüksek Mn değerleri (0.39) Kral-97 çeşidinden elde edilmiştir $(P<0.01)$. Akhisar-98 çeşidinden 0.35 ppm mangan miktarı elde edilerek bu çeşidi takip etmiştir. En düşük değerler (0.18) ise Tarm92 çeşidinden elde edilmiştir (Çizelge 6). Gazda çeşidinden $0.47 \mathrm{ppm} \mathrm{Zn}$ değeri elde edilmiştir $(P<0.01)$. Lord çeşidi 0.43 ppm çinko değeri ile bu çeşidi takip etmiştir. En düşük $\mathrm{Zn}$ değerleri (0.24) Karatay-94 çeşidinden elde edilmiştir (Çizelge 6). Tarm-92 çeşidinden en yüksek Na değerleri (5.13) elde edilmiştir $(P<0.01)$. Zeynelağa çeşidi 4.38 ppm sodyum miktarı ile bu çeşidi izlemiştir. Gazda çeşidinden ise en düşük (3.14) Na değerleri elde edilmiştir (Çizelge 6). Al Karaki Al Momani (2011) hidroponik yeşil arpanın N, $\mathrm{P}, \mathrm{K}, \mathrm{Mg}, \mathrm{Ca}, \mathrm{Cu}, \mathrm{Mn}, \mathrm{Zn}$ ve $\mathrm{Fe}$ mineral madde içeriklerini sırasıyla \%4.08, 0.61 ve 0.86 ile $3.78,3.19$, 16, 23, 58 ve 92 ppm olarak belirlemişlerdir. Dung et al. (2010) hidroponik arpa çiminin $\mathrm{Ca}, \mathrm{K}, \mathrm{Mg}, \mathrm{P}, \mathrm{S}, \mathrm{Al}$, $\mathrm{Cu}, \mathrm{Fe}, \mathrm{Mn}, \mathrm{Mo}, \mathrm{Na}$ ve $\mathrm{Zn}$ mineral madde içeriklerini sırasıyla, \%0.06, $0.26,0.13,0.26$ ve 0.17 ile $5.5,13.4$, $52.0,12.2,1.7,830.9$ ve 23 ppm olarak belirlemişlerdir. Fazaeli et al. (2011) hidroponik arpa çiminin Ca, P, K, $\mathrm{Mg}, \mathrm{Fe}, \mathrm{Mn}, \mathrm{Zn}$ ve $\mathrm{Cu}$ mineral madde içeriklerini sirasılyla, \%0.32, $0.43,0.37$ ve 0.21 ile $237,18.5,21.1$ ve 7.7 ppm olarak tespit etmişlerdir.

Çizelge 6. Farklı çeşitlerin mineral madde içerikleri üzerine etkileri.

Table 6. The effects of different varieties on mineral matter content.

\begin{tabular}{|c|c|c|c|c|c|c|c|c|c|c|}
\hline \multirow{2}{*}{ Çeşitler } & $\mathbf{N}$ & $\mathbf{P}$ & $K$ & $\mathrm{Ca}$ & Mg & $\mathbf{F e}$ & $\mathrm{Cu}$ & Mn & Zn & $\mathrm{Na}$ \\
\hline & $\%$ & \multicolumn{9}{|c|}{ ppm } \\
\hline Gazda & $3.00 \mathrm{ab}$ & $0.60 \mathrm{~g}$ & 35.22 cde & $4.55 \mathrm{e}$ & $5.31 \mathrm{e}$ & $0.39 \mathrm{f}$ & $0.55 \mathrm{a}$ & $0.32 \mathrm{e}$ & $0.47 a$ & 3.14 I \\
\hline Aydanhanım & $2.95 a b c$ & $0.58 \mathrm{gh}$ & $36.16 \mathrm{bc}$ & $7.21 \mathrm{a}$ & $5.45 \mathrm{e}$ & $0.58 \mathrm{a}$ & $0.38 c$ & $0.34 c$ & $0.26 \mathrm{~h}$ & $3.29 \mathrm{~h}$ \\
\hline Zeynelağa & $2.91 \mathrm{c}$ & $0.71 \mathrm{e}$ & $35.18 \mathrm{cde}$ & $5.39 \mathrm{~d}$ & $5.88 \mathrm{~d}$ & $0.53 \mathrm{~b}$ & $0.45 b$ & $0.30 \mathrm{f}$ & $0.35 \mathrm{~d}$ & $4.38 \mathrm{~b}$ \\
\hline Karatay-94 & $3.03 \mathrm{a}$ & $0.56 \mathrm{~h}$ & 34.77 cde & $5.81 \mathrm{c}$ & $7.09 a$ & $0.57 \mathrm{a}$ & $0.36 \mathrm{~d}$ & $0.32 \mathrm{e}$ & 0.24 I & $3.44 \mathrm{~g}$ \\
\hline Atılır & $2.98 \mathrm{abc}$ & $0.74 \mathrm{~d}$ & $35.51 \mathrm{bcd}$ & $6.33 \mathrm{~b}$ & $5.44 \mathrm{e}$ & $0.50 \mathrm{c}$ & $0.54 \mathrm{a}$ & $0.33 \mathrm{~d}$ & $0.42 c$ & $3.88 \mathrm{e}$ \\
\hline Hilal & $2.99 a b c$ & I I I & $34.23 \mathrm{e}$ & $6.42 b$ & $4.87 \mathrm{f}$ & $0.42 \mathrm{e}$ & $0.54 \mathrm{a}$ & $0.26 \mathrm{~h}$ & $0.33 \mathrm{e}$ & $3.43 \mathrm{~g}$ \\
\hline Akhisar-98 & $2.77 \mathrm{~d}$ & $0.85 \mathrm{~b}$ & $35.42 \mathrm{bcd}$ & $5.95 \mathrm{c}$ & $6.54 b$ & $0.39 \mathrm{f}$ & $0.28 \mathrm{e}$ & $0.35 \mathrm{~b}$ & $0.29 \mathrm{f}$ & $4.23 c$ \\
\hline Lord & $2.93 \mathrm{bc}$ & $0.68 \mathrm{f}$ & 36.33 b & $7.11 \mathrm{a}$ & $4.91 \mathrm{f}$ & $0.47 \mathrm{~d}$ & $0.28 \mathrm{e}$ & $0.28 \mathrm{~g}$ & $0.43 \mathrm{~b}$ & $3.74 \mathrm{f}$ \\
\hline Kral-97 & $2.48 \mathrm{e}$ & $0.88 a$ & $35.55 \mathrm{bcd}$ & $6.27 \mathrm{~b}$ & $6.23 c$ & $0.49 c$ & $0.55 \mathrm{a}$ & $0.39 a$ & $0.27 \mathrm{~g}$ & $4.09 \mathrm{~d}$ \\
\hline HSD & $0.06^{\star \star}$ & $0.01^{\text {** }}$ & $0.73^{* *}$ & $0.13^{\text {** }}$ & $0.12^{\star *}$ & $0.01^{\text {** }}$ & $0.01^{\text {** }}$ & $0.01^{\star \star}$ & $0.007^{\star \star}$ & $0.03^{\text {** }}$ \\
\hline
\end{tabular}

*; P<0.05, **; $P<0.01$, HSD; Güvenilir önemli fark, Ns; Önemli değil. 
Hayvanların büyüme, gelişim, üreme, sağlıklı ve ideal vücut fonksiyonları için mineral maddeler hayati önem taşırlar. Mineral madde miktarlarındaki aşırılık ya da eksiklik yem kalitesini olumsuz etkilemekte ve raşitizm, süt humması, yavru atma, halsizlik, iştahsızlık, tetani gibi hastalıklara sebep olmaktadır (Kumar and Soni 2014).

Benzer konularda daha önce yapılan araştırmalarda elde edilen değerler bizim bulgularımızla örtüşürken, bazılarında daha yüksek, bazılarında ise daha düşük değerler elde edildiği saptanmıştır. Aynı konularda farklı sonuçların elde edilmesi; tohum çeşit ve kalitesi, su kalitesi ve $\mathrm{pH}$, sulama süresi ve sıklığı, ön ıslatma süresi, bitki besi elementi varlığı, sıcaklık, nem oranı, ışık yoğunluğu ve pozisyonu, tohum yoğunluğu ve yetiştirme süresi gibi uygulamaların benzerliği ve farklılığından kaynaklanabileceği fikrini uyandırmaktadır (Sneath and McIntosh 2003; Dung et al., 2010; Fazaeli et al., 2012).

\section{SONUÇ}

Araştırma sonuçlarına göre, farklı çeşitler arasında en yüksek yeşil yem verimi ve yeşil yem tohum oranı Atılır çeşidinden elde edilmiştir. Zeynelağa ve Tarm-92 çeşitleri yüksek yeşil yem değerleri ile bu çeşidi takip etmiştir. En yüksek kuru madde oranı, $P$ ve $M n$ değerleri Kral-97 çeşidinden elde edilirken, en düşük kuru madde kayıpları Hilal ve Akhisar-98 çeşitlerinden elde edilmiştir. Yeşil yem verimi ve yeşil yem tohum oranı $^{-1}$ artışıyla birlikte kuru madde oranı değerlerinin düştüğü ve kuru madde kayıplarının arttığı görülmektedir. En yüksek ham protein kazançları Atılır ve Hilal çeşitlerinden elde edilmiştir. En yüksek bitki boyu, ham protein, ham yağ, ADL, N ve Mg değerleri Karatay-94 çeşidinden elde edilirken, en yüksek kök uzunluğu değerleri Akhisar-98 çeşidinden elde edilmiştir. En yüksek ham kül, ham selüloz, ADF ve NDF değerleri sırasıyla Akhisar-98, Tarm-92, Aydanhanım, ve Atılır çeşitlerinden elde edilmiştir. En yüksek metabolik enerji değerleri ise Zeynelağa çeşidinden elde edilmiştir. En yüksek K ve Na değerleri Tarm-92 çeşidinden elde edilirken en yüksek $\mathrm{Zn}$ değerleri ise Gazda çeşidinden elde edilmiştir. En yüksek Ca değerleri Aydanhanım ve Lord çeşidinden elde edilirken, en yüksek Fe değerleri Aydanhanım, Tarm92 ve Karatay-94 çeşitlerinden elde edilmiştir. En yüksek Cu değerleri ise Gazda, Kral-97, Atılır ve Hilal çeşitlerinden elde edilmiştir.

Yüksek yeşil yem verimi ve ham protein kazançları yönüyle Atılır çeşidinin, düşük kuru madde kaybı ve yüksek ham protein kazancı değerleri birlikte dikkate alındığında Hilal çeşidinin dikkati çektiği görülmektedir. Metabolik enerji değerleri göz önünde bulundurulduğunda ise Zeynelağa çeşidi tavsiye edilebilir niteliktedir.

\section{KAYNAKLAR}

Akbağ HI., Türkmen OS., Baytekin H and Yurtman IY., 2014. Effects of harvesting time on nutritional value of hydroponic barley production. Turkish Journal of Agricultural and Natural Sciences Special Issue: 2: 17611765.

Al Ajmi A., Ali Salih A., Kadim I and Othman Y., 2009. Yield and water use efficiency of barley fodder produced under hydroponic system in GCC countries using tertiary treated sewage effluents. Journal of Phytology, 1(5): 342348.

Alçiçek A., Kılıç A., Ayhan V ve Özdoğan M., 2010. Türkiye'de Kaba Yem Üretim ve Sorunları. Ziraat Mühendisliği VII. Teknik Kongresi, 11-15 Ocak, Ankara.

Alkan FR ve Kandemir N., 2015. Tokak yerel arpa çeşidi içinden seçilen safhatların bazı gıda, yem ve tarımsal özellikler bakımından varyasyonları. Tarla Bitkileri Merkez Araştırma Enstitüsü Dergisi, 24(2): 124-139.

Al-Karaki GN., Al-Ajmi A and Othman Y., 2007. Seed germination and early root growth of three barley cultivars as affected by temperature and water stress. American-Eurasian Journal Agriculture and Environment Science, 2(2): 112-117.

Al-Karaki GN and Al-Momani N., 2011. Evaluation of some barley cultivars for green fodder production and water use efficiency under hydroponic conditions. Jordan Journal of Agricultural Sciences, 7(3): 448-457.

Ata M., 2016. Effect of hydroponic barley fodder on awassi lambs performance. Journal of Biology, Agriculture and Healthcare, 6(8): 60-64.

Dung DD., Godwin IR and Nolan JV., 2010. Nutrient content and in sacco digestibility of barley grain and sprouted barley. Journal of Animal and Veterinary Advances, 9: 2485-2492.

Emam MSA., 2016. The sprout production and water use efficiency of some barley cultivars under intensive hydroponic system. Middle East Journal of Agriculture Research, 5(2): 161-170.

Fazaeli H., Golmohammadi HA., Shoayee AA., Montajebi N and Mosharraf S., 2011. Performance of feedlot calves fed hydroponics fodder barley. Journal of Agricultural Science Technology, 13: 367-375.

Fazaeli H., Golmohammadi HA., Tabatabayee SN and AsgariTabrizi M., 2012. Productivity and nutritive value of barley green fodder yield of hydroponic system. World of Applied Sciences Journal, 16: 531-539.

Guo TR., Zhang GP., Zhou MX., Wu FB and Chen JX., 2003. Genotypic difference in plant growth and mineral 
composition in barley under aluminum stres. Agricultural Sciences in China, 2(5): 494-501.

Hafla AN., Soder KJ., Brito AF., Rubano MD and Dell CJ., 2014. Effect of sprouted barley grain supplementation of an herbage-based or haylage-based diet on ruminal fermentation and methane output in continuous culture. Journal of Dairy Science, 97(12): 7856-7869.

JMP 2007. Statistic and Graphics Guide. Release 7, SAS Institute Inc, Cary, USA.

Karaşahin M., 2014. Kaba yem kaynağı olarak hidroponik arpa çimi üretiminde kuru madde ve ham protein verimleri üzerine farklı uygulamaların etkileri. Süleyman Demirel Üniversitesi Ziraat Fakültesi Dergisi, 9(1): 27-33.

Karaşahin M., 2017. Farklı gübreleme ve yetiştirme süresi uygulamalarının hidroponik arpa (Hordeum vulgare L. conv. distichon) çimi üzerine etkileri. Iğdır Üniversitesi Fen Bilimleri Enstitüsü Dergisi, 7(1): 39-46.

Kumar K and Soni A., 2014. Elemental ratio and their Importance in feed and fodder. International Journal of Pure \& Applied Bioscience, 2(3): 154-160.

Lee SY., Lee JH and Kwan TO., 2002. Varietals differences in seed germination and seedling vigor of Korean rice varieties following dry heat treatment. Seed Science \& Technology, 30: 311-321.

Sneath R and Mclntosh F., 2003. Review of hydroponic fodder production for beef cattle. http://www.qcl.farmonline.com.au/files/48/20/01/00001 2048/Hydroponicfodder.pdf. [Access: November 15, 2016].

Topal A., 1993. Konya ekolojik şartlarında bazı arpa çeşitlerinde (Hordeum vulgare L.) farklı ekim zamanlarının kışa dayanıklıık, dane verimi, verim unsurları ve kalite özelliklerine etkileri üzerine bir araştırma. Doktora Tezi (Basılmamış), Selçuk Üniversitesi Fen Bilimleri Enstitüsü, Konya.

Topal A., Sade B., Soylu S., Akar T., Mut Z., Ayrancı R., Sayım İ., Özkan I ve Yılmazkart M., 2015. Ulusal Hububat Konseyi, Arpa-Çavdar-Yulaf-Tritikale Raporu. http://uhk.org.tr/dosyalar/uhkarpa_kasim2015.pdf. [Erişim: 15 Şubat 2017].

TSE 2008. Hayvan Yemleri Metabolik (çevrilebilir) Enerji Tayini Kimyasal Metot. Standart No. 9610, Ankara, Türkiye.

Van Soest P and Robertson JB., 1985. A Laboratory Manual For Animal Science. Cornell University, Ithaca, New York, USA.

Yolcu H ve Tan M., 2008, Ülkemiz yem bitkileri tarımına genel bir bakış. Tarım bilimleri Dergisi, 14(3): 303-312.

Yousof FI., Amer KA and Mersal IF., 2017. Screening os some Egyptians barley cultivars for sprouted green fodder yield under hydroponic system. International Journal of Technical Research \& Science, 1(10): 364-371. 